Peasants on the Edge 
THIS PAGE INTENTIONALLY LEFT BLANK 


\section{PEASANTS \\ ON THE EDGE \\ Crop, Cult, and Crisis in the Andes}

by William P. Mitchell

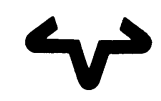

University of Texas Press, Austin 


\section{To my children, Sean and Nicholas, and to the memory of Gerald Freed}

Copyright (C) I 99 I by the University of Texas Press All rights reserved

Printed in the United States of America

First Edition, I99 I

Requests for permission to reproduce material from this work should be sent to Permissions, University of Texas Press, Box 7819, Austin, Texas $78713-7819$.

Q The paper used in this publication meets the minimum requirements of American National Standard for Information Sciences-Permanence of Paper for Printed Library Materials, ANSI Z39.48-I 984.

Library of Congress Cataloging-in-Publication Data

Mitchell, William P., 1937-

Peasants on the edge : crop, cult, and crisis in the Andes / by William P. Mitchell. - Ist ed.

p. $\quad \mathbf{c m}$.

Includes bibliographical references and index.

ISBN: 0-292-72145-5

I. Indians of South America-Peru-Quinua (Humanga)-Agriculture. 2. Indians of South America-Peru-Quinua (Humanga)Economic conditions. 3. Indians of South America-Peru-Quinua (Humanga)-Politics and government. 4. Peasantry-Peru-Quinua (Humanga) 5. Quinua (Humanga, Peru)-Religious life and customs. 6. Quina (Humanga, Peru)-Social conditions. I. Title.

F3429.1.Q56M 58 I991

$985^{\prime} .292-\mathrm{dc} 20$

$90-47300$ 